\title{
The accuracy of acetylcholinesterase reaction in rectal suction biopsy in the diagnosis of Hirschsprung's disease
}

\section{A acurácia da reação da acetilolinesterase na biópsia por sucção retal no diagnóstico da doença de Hirschsprung}

Elizabeth S. Gugelmin'; Luiz Fernando B. Torres²

\section{key word abstract}

Hirschsprung's disease

Suction rectal biopsy with acetylcholinesterase (AChE) histochemistry has been recognized as a reliable

Rectal biopsy

method for the diagnosis of Hirschsprung's disease (HD). This study compares the final pathologic diag-

Colectomy nosis made on paraffin embedded material of 68 colectomy specimens with the histochemical AChE

Acetylcholinesterase reaction from the same patients previously diagnosed as HD by rectal suction biopsy at the Hospital Infantil Pequeno Príncipe (Curitiba, Brazil) from 1988 to 1999. The group included 58 male and ten female patients with ages ranging from 7 days to 10 years. Thirty-six patients (52.94\%) where under 1 year of age at time of surgery. Two of the 68 patients had previous normal histochemical reactions for AChE: one of them resulted a normal ganglionic segment of bowel and the other one was a 15day-old boy with total colonic aganglionosis, the only false-negative result in this series. Two patients had inconclusive results and because untreatable clinical symptoms also received surgical treatment. One of them resulted a normal ganglionic bowel and the other one was diagnosed as HD. All surgical specimens from the other 64 patients resulted in various extents of aganglionosis presenting prominent nerve trunks in the submucosal and myenteric plexuses, confirming the previous AChE histochemical diagnosis. In three cases there was total colonic aganglionosis. In this study the rectal suction biopsy associated with the histochemical method of AChE, performed days, months or sometimes years before surgery, resulted in a diagnostic accuracy rate of $95.59 \%$, a positive predictive value of $100 \%$ and there were no false-positive results.

resumo

A biópsia de reto por sucção associada à histoquímica enzimática pela acetilcolinesterase (AChE) tem sido reconhecida como um método confiável para o diagnóstico da doença de Hirshsprung (HD). Este estudo compara o diagnóstico patológico final de 68 peças de colectomias incluídas em parafina com o diagnóstico prévio de HD através da reação histoquímica da AChE em biópsia por suç̧ão retal dos mesmos pacientes, todos operados no Hospital Infantil Pequeno Príncipe, de Curitiba, entre 1988 e 1999. No grupo há 58 pacientes masculinos e dez femininos com idades variando entre 7 dias e 1 ano, sendo que 33 pacientes (52,94\%) tinham menos de 1 ano de idade no momento da cirurgia. Dos 68 pacientes, dois tiveram reação prévia normal pela AChE, porém, como persistiam com quadro de suboclusão intestinal, foram levados à cirurgia; um deles resultou HD, padrão aganglionose total do cólon, o único caso falso-negativo deste estudo. Outros dois pacientes tiveram resultado inconclusivo pela AChE, e um deles resultou HD no exame da colectomia. Todas as colectomias dos demais 64 pacientes resultaram agangliônicas (HD), apresentando proeminência de troncos nervosos nos plexos submucoso e mioentérico, confirmando o diagnóstico histoquímico prévio pela AChE. Em três casos havia aganglionose colônica total. Neste estudo a biópsia retal por sucção associada ao método histoquímico da AChE, realizado dias, meses ou anos antes da cirurgia, apresentou taxa de acurácia diagnóstica de 95,59\%, valor preditivo positivo de $100 \%$ e nenhum resultado falso-positivo. unitermos

Doença de Hirschsprung

Biópsia retal

Colectomia

Acetilcolinesterase 


\section{Introduction}

Hirschsprung's disease (HD) is a congenital disorder of intestinal motility with an incidence of approximately one in 5 thousand infants. Although it has been known for more than a hundred years, HD still challenges clinicians, diagnostic pathologists, scientists and researchers to understand the pathogenesis of the disorder due to its genetic complexity ${ }^{(17)}$. The disease is defined by an absence of ganglion cells in the distal rectum and in a variable length of more proximal intestine, more rarely into the small bowel, resulting in absent motility of the aganglionic segment and obstructive symptoms. The aganglionic bowel is characterized by the presence of hypertrophic nerve fibers that can be demonstrated histochemically through the AChE reaction in the muscularis mucosa and submucosa of rectal suction biopsies. In order to detect the diagnostic accuracy of AChE histochemical reaction in rectal suction biopsies we decided to compare the results of 68 patients with HD previously diagnosed by this method with the final pathological diagnosis obtained from the analysis of their surgical colectomy specimens defined as gold standard.

\section{Materials and method}

A total of 68 patients, 64 of which with previous diagnosis of $\mathrm{HD}$ made by $\mathrm{AChE}$ histochemical reaction in rectal suction biopsies from 1988 to 1999 were submitted to a further colectomy at Hospital Infantil Pequeno Príncipe in Curitiba, Brazil.

Days, months or years prior to surgical treatment all 68 patients were submitted to rectal suction biopsy with at least two samples obtained at $2 \mathrm{~cm}$ and $3 \mathrm{~cm}$ or $2 \mathrm{~cm}$ and $4 \mathrm{~cm}$ from the mucocutaneous junction. The biopsies were obtained through the Noblett's modified biopsy instrument (Genito-urinay Instruments, London, UK). Each specimen measuring around $3 \mathrm{~mm}$ was kept moisted over a saline soaked filter paper, then oriented on a block of animal liver, and then frozen in liquid nitrogen. Cryostat sectioning was performed in a plane perpendicular to the mucosal surface. Each block was trimmed until submucosa was visible in the sections, and eight 6-um-thick sections collected on the same slide were stained with hematoxylin-eosin (HE); six further 12-um thick sections were collected in three different slides for AChE histochemistry. After evaluating the HE sections and the quality of $\mathrm{AChE}$ technique, all remaining tissue was defrosted, placed into $10 \%$ buffered formalin and embedded in paraffin, cut and stained with HE for normal histological observation. The AChE activity was analyzed according to the modified reaction of Karnovsky and Roots $(9,10)$.

Immediately after the surgical treatment the resected bowels were received fresh in the laboratory of pathology, opened longitudinally by the antimesenteric border, washed in tap water and then fixed in $10 \%$ formalin pinned to a piece of wood or cork to keep their shape. After 24 hours of fixation a longitudinal strip was cut along the specimen from proximal to distal end. This strip was then cut in smaller pieces, of approximately $2 \mathrm{~cm}$ each, to fit in numbered cassettes (Figure 1). The material was then processed, embedded in paraffin and stained with HE. This method resulted in three to ten numbered slides orientated in a way that the whole length of the resected colon could be restored, the extent of aganglionosis could be determined, the transitional zone detected, as well as the status of the proximal portion ascertained.

Taking the diagnosis after colectomy as gold standard we estimated accuracy, specificity, positive and negative predictive values.

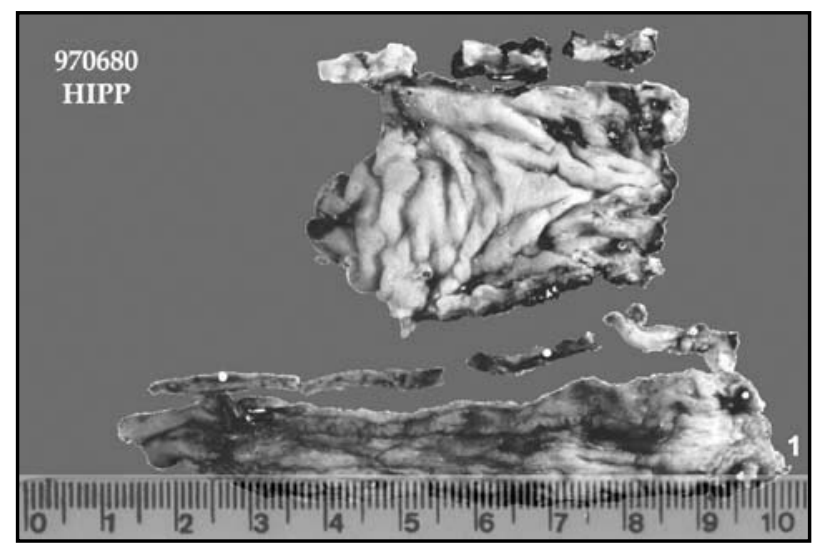

Figure 1 - Surgical specimen from a pull-through operation (97B-680). The distal segment (longer) is composed by mucosa and submucosa only (Soave procedure); the proximal segment (shorter) contains all wall layers. The illustration shows the technique of cutting a longitudinal strip along the specimen and then in smaller pieces to fit the cassettes for histological processing

\section{Results}

\section{Clinical observations}

The 68 patients included 58 males and ten females whose ages at the time of pull-through surgery ranged from 7 days to 10 years, with a median age of 21 months. Their main symptom was refractile intestinal obstruction and the clinical presumptive diagnosis, based on physical examination and radiologic findings, was HD. All patients were submitted to rectal suction biopsy stained with AChE to confirm the clinical hypothesis (Graph 1). 


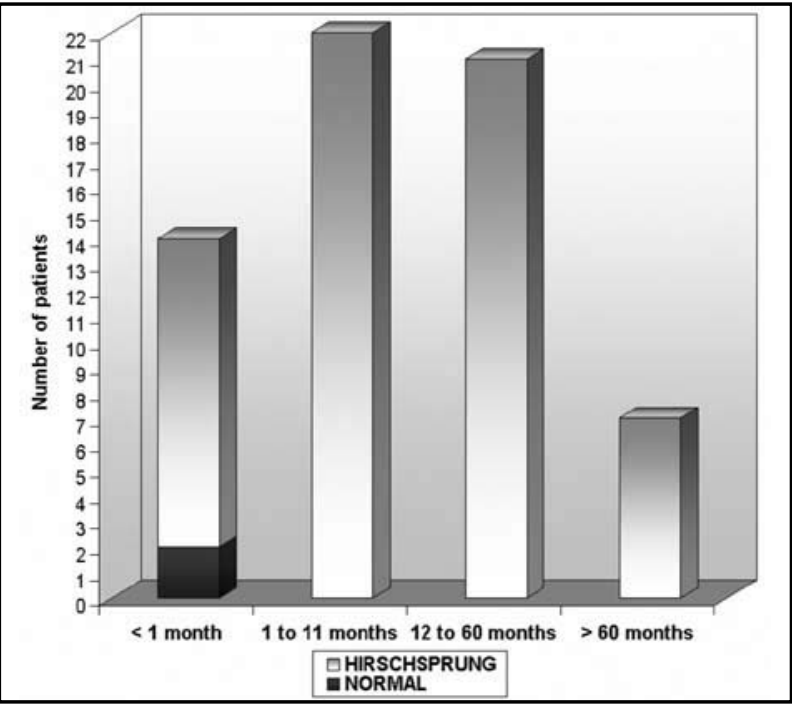

Graph 1 - Age groups (in months) of the 68 patients surgically treated with pullthrough colectomy

\section{Acetylcholinesterase assay}

In 64 of the 68 cases (94.1\%) the rectal suction biopsies stained with $\mathrm{AChE}$ histochemistry were diagnostic of HD, showing absence of ganglion cells in the serial sections and increased number of AChE-positive stained nerve fibers in the submucosa, muscularis mucosa or lamina propria. The nerve fibres showing increased acetylcholinesterase activity were stained dark brown to black (Figures $\mathbf{2 A}$ and $\mathbf{2 B}$ ). In two of the 68 cases $(2.9 \%)$ rectal suction biopsy and $\mathrm{AChE}$ reaction resulted normal; in one of them there were no ganglion cells present in the submucosa even in serial sections, but there was also no increase in hypertrophic AChE-positive nerve fibers in the muscularis mucosa or submucosa. In further two of the 68 cases (2.9\%) the rectal suction biopsy and AChE reaction resulted inconclusive: one due to severe inflamation associated with ulceration and necrosis of the mucosa and the other due to technical artifacts during processing.

\section{Colectomy analysis}

The macroscopic aspects of the ressected bowel were similar since Soave procedures were performed in all 68 patients. In the Soave procedure, the rectal mucosa is stripped from the underlying muscle in a way that the distal end of the specimen (rectal sleeve) contains only mucosa and submucosa ${ }^{(18)}$.

Histological examination in 66 cases out of 68 specimens (97\%) confirmed the diagnosis of Hirschsprung's disease showing absence of ganglion cells and presence of prominent nerve trunks in the submucosal and myenteric plexuses

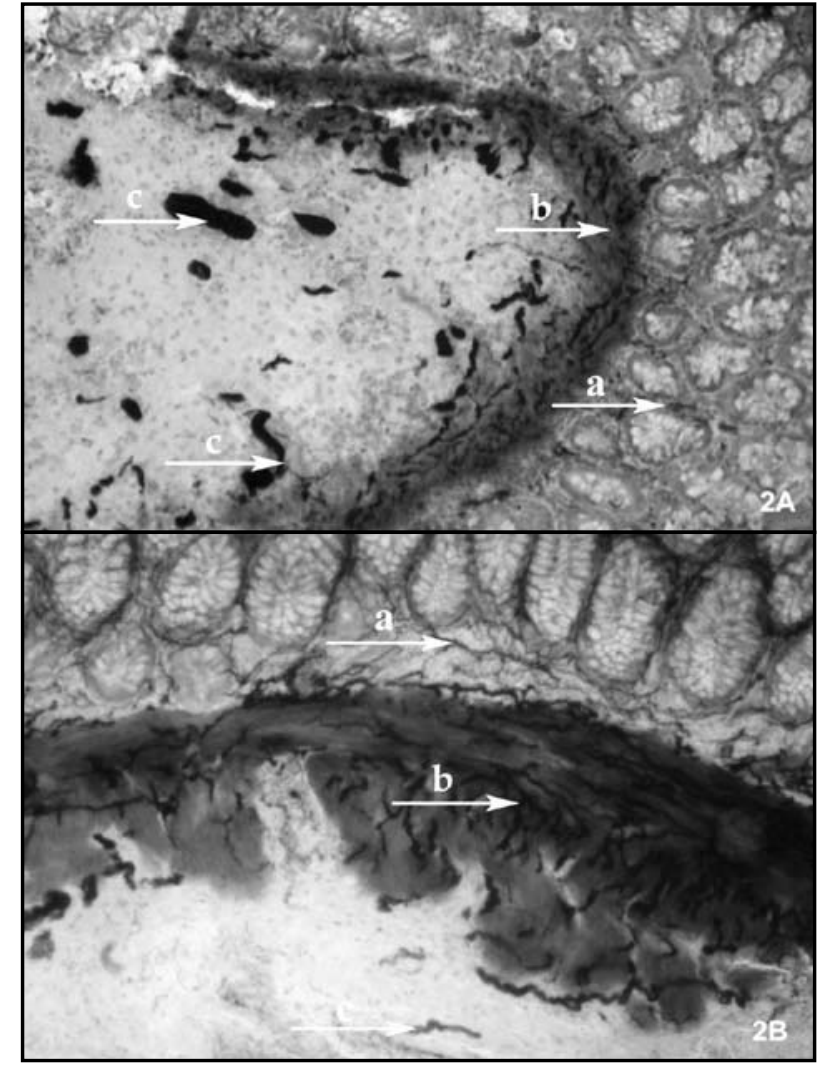

Figures 2A and 2B - Suction rectal biopsy of patient (E98-94) with HD stained by AChE histochemical reaction showing numerous thick and irregular dark brown nerve fibers on the mucosa (a), muscularis mucosa (b) and submucosa (c). $(A \times 100 ; B \times 400)$

(Figure 3). Three of these patients had total colonic aganglionosis, so that no evidence of nerves in the submucosa or myenteric plexus was seen and the muscle coats were tightly apposed (Figure 4). There were two patients whose surgical specimens resulted normally ganglionic.

The results of the previous suction rectal biopsies stained with AChE reaction from the 68 patients were then compared to the final paraffin diagnosis in the respective surgical specimens (Table 1).

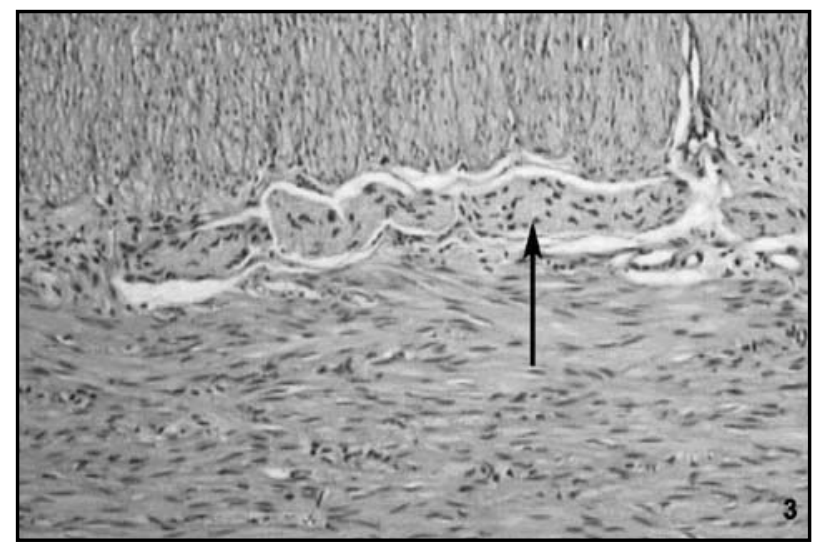

Figure 3 - Histological section of colectomy of patient (99B-1018) with HD stained by H\&E showing hypertrophic nerves (arrow) in the myenteric plexus (x 100) 
Table 1

Correlation between the final pathologic diagnosis of HD in colectomy specimens with the previous diagnosis made by AChE reaction in rectal suction biopsy of 68 patients analysed between 1988 e 1999

HD diagnosis in rectal suction biopsies by AChE reaction

Positive

Negative

Inconclusive

Total
HD diagnosis in colectomies

$\begin{array}{ccc}\text { Present } & \text { Absent } & \text { Total } \\ 64 & 0 & 64 \\ 1 & 1 & 2 \\ 1 & 1 & 2 \\ 66 & 2 & 68\end{array}$

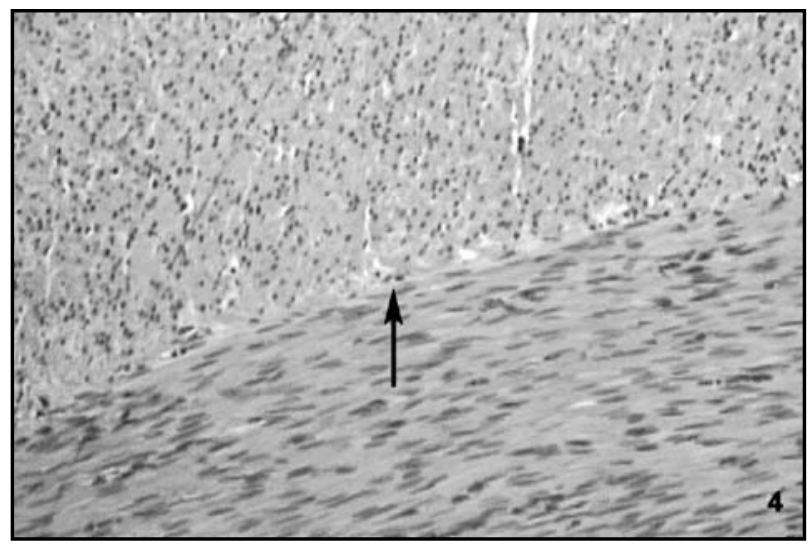

Figure 4 - Histological section of colectomy of patient (98B-1103) with HD, total colonic aganglionosis, showing total absence of the myenteric plexus and tightly apposed muscle coats (arrow) (H\&E x 100)

\section{Statistical analysis}

Statistical analysis showed an accuracy rate of $95.59 \%$, specificity of $50 \%$, positive predictive value of $100 \%$ and negative predictive value of $50 \%$.

\section{Discussion}

Rectal suction biopsy associated with the histochemical demonstration of AChE activity has been worldwide used in the last 20 years as a definitive method for the diagnosis of HD, as well as in excluding this disease when evaluating a child with chronic constipation ${ }^{(10,15)}$. The rectal biopsy was established by Swenson in $1955^{(19)}$, and Noblett first described suction rectal biopsy with a modified biopsy instrument in $1969^{(14)}$. Since then, several studies of the widespread applicability of rectal suction biopsy and AChE histochemistry have continuously been reported $^{(1-7,11-13,15,16,19,21,22)}$.

Children with intractable constipation need to be assessed by all resources since it can be caused by various factors. In those children with severe symptoms it is important to exclude the possibility of HD by rectal biopsy. It is also fundamental to the clinician to understand the symptoms, to preview the risks, the prognosis and to plan the treatment. The identification of ganglion cells in an adequate rectal suction biopsy may need up to a hundred or more sections in a normal individual ${ }^{(1)}$. There is a welldocumented paucity of ganglion cells in the distal $2-3 \mathrm{~cm}$ of rectum ${ }^{(20)}$ so that they can be difficult to find, and nerve trunks may also be prominent in the submucosa in this region, which can further mislead the unwary pathologist. Patients with total colonic aganglionosis may present diagnostic difficulties even with an inordinate number of serial sections ${ }^{(11)}$.

The histochemical detection of excessive AChE activity, both from biopsies of the anal mucosa and within the first $3 \mathrm{~cm}$ of the rectum proximal to the anal ring, permits a precise and reliable means of diagnosis of HD with good accuracy rate, simplicity of the technique and absence of complications. However, a pathologist experienced in preparing and reading these specimens is absolutely essential $(11,13,16,21)$. The use of immunohistochemistry with ganglion cell markers such as NSE and synaptophysin or, for nerve cell processes, such as $\$ 100$, has been advocated but showed frequent inconsistency and lack of architectural pattern that is useful for HD diagnosis ${ }^{(8)}$. This technique has been used mainly to assess neurodegenerative diseases in rectal suction biopsies.

All the 68 patients included in this study presented clinically with intestinal obstruction in the neonatal period, or later on with severe chronic constipation, abdominal distension and failure to thrive. The patients were initially submitted to a rectal suction biopsy and histochemistry to show AChE activity and all cases diagnosed as HD (64 cases) were submitted to further surgical treatment. Two patients had inconclusive results in the AChE 
histochemistry, even in the repeated study, and two had normal reactions for $\mathrm{AChE}$, but since clinical evidences were highly indicative of $\mathrm{HD}$ they were also submitted to surgical treatment. In the surgical specimens from both cases whose histochemistry resulted inconclusive, one was diagnosed as HD and the other one was normally ganglionic. In the surgical specimens from both cases whose histochemistry resulted normal, one was normally ganglionic and one was diagnosed as total colonic aganglionosis, the only false-negative result in this study. In our experience, patients submitted to rectal suction biopsy were lactants who failed to pass meconium in the first 48 hours or infants and children with chronic constipation. We observed that those children who presented with a full rectum associated with fecal incontinence or encopresis, absence of pondero-statural deficit and any psychological disturbance, himself or in the parents, were most frequently normally ganglionic in rectal biopsy and probably had constipation of other functional cause.

The rectal suction biopsy associated with the histochemical method for demonstrating AChE activity presented a positive predictive value of $100 \%$. There were no false-positive results in this study. Meier-Ruge et al., in $1972^{(13)}$, showed $100 \%$ accuracy in 60 selected cases of suction biopsies and $\mathrm{AChE}$ reactions when compared with the surgical specimens. Lake et al., in $1978^{(12)}$, stated the AChE method as the most reliable if compared with the rectal suction biopsy routinely processed in paraffin and stained with hematoxylin and eosin (H\&E). Wakely and McAdams, in 1984(21), found an accuracy rate of $95 \%$ for the histochemical method, if compared with rectal suction biopsies routinely processed and stained with $\mathrm{H \& E}$ (83\% accuracy); and Park et al., in $1992^{(16)}$, found $97 \%$ accuracy for the histochemical method stained with $\mathrm{AChE}$, but when routinely processed and stained with $H \& E$ the suction biopsy had an accuracy of $74 \%$ in their series. In our study we found an accuracy rate of $95.59 \%$ comparing nonselected rectal suction biopsies stained with $\mathrm{H} \& E$ plus the histochemical method of AChE, when compared with the surgical specimens from colectomies.

\section{Acknowledgements}

The authors wish to thank the clinical staff of Hospital Infantil Pequeno Príncipe for referring the cases for suction biopsy and Mrs. Renata L. Giron for technical assistance.

\section{References}

I. Andrassy, R. J.; Issacs, H.; Weitzman, J. J. Rectal suction biopsy for the diagnosis of Hirschsprung's disease. Ann Surg, v. 193, p. 4|9-24, 1981.

2. Ariel, I. et al. Rectal mucosal biopsy in aganglionosis and allied conditions. Hum Pathol, v. I 4, p. 99I-5, 1983.

3. Challa, V. R. et al. Histological diagnosis of Hirschsprung's disease. A value of concurrent hematoxylin and eosin and cholinesterase staining of rectal biopsies. Am J Clin Pathol, v. 88, p. 324-8, 1987.

4. Chow, C. W.; Chan, W. C.; Yue, P. C. K. Histochemical criteria for the diagnosis of Hirschsprung's disease in rectal suction biopsies by acetylcholinesterase activity.J Pediatr Surg, v. 12 , p. 675-80, 1977.

5. De Mingo Misena, L. et al. Diagnóstico histopatológico de la enfermedad de Hirschsprung. Nuestra experiencia en dieciocho años. Cir Pediatr, v. 4, p. 181-4, 1991.

6. Ferreira, C. T. et al. A biópsia de sucção retal e a técnica histoquímica da acetilcolinesterase no diagnóstico diferencial da constipação na infância. Gastroenterol Endosc Dig, v. I3, p. 5-8, 1994.
7. Gugelmin, E. S.; Bleggi-Torres, L. F.; Sabbaga, C. C. Aplication of suction rectal biopsy in the diagnosis of Hirschsprung's disease.J Pediatr, v. 66, p. 171-4, 1990.

8. Hall, C. L., Lampert, P.W. Immunohistochemistry as an aid in the diagnosis of Hirschsprung's disease. Am J Clin Pathol, v. 83, p. 177-8I, 1985

9. Hanker, J. S.; Anderson, W. A.; Bloom, F. E. Osmiophilic polymer generation: catalysis by transition metal compounds in ultrastructural cytochemistry. Science, v. 175, p. 991-3, 1972.

10. Karnovski, M. J.; Roots, L.A "direct-coloring"thiocholine method for cholinesterase. J Histochem Cytochem, v. 12, p. 219-21, 1964.

I I. Lake, B. D.; Malone, M.; Risdon, R. A. Acetylcholinesterase in the diagnosis of Hirschsprung's disease, including a comment on intestinal neuronal dysplasia. Pediatric Pathology, v. 9, p. $351-4,1989$

12. Lake, B. D. et al. Hirschsprung's disease. An appraisal of histochemically demonstrated acetylcholinesterase activity in suction rectal biopsy specimens as an aid to diagnosis. 
Arch Path Lab Med, v. 102, p. 244-7, 1978.

13. Meier-Ruge, W. et al. Acetylcholinesterase activity in suction biopsies of the rectum in the diagnosis of Hirschsrpung's disease.J Ped Surg, v. 7, p. II-17, 1972.

14. Noblett, H. R. A rectal suction biopsy tube for use in the diagnosis of Hirschsprung's disease. J Pediatr Surg, v. 4, p. 406-9, 1969.

15. NOGUEIRA, A. M. et al. Usefulness of immunocytochemical demonstration of neuron-specific enolase in the diagnosis of Hirschsprung's disease. J Pediatr Gastroenterol Nutr, v. I (4), p. 496-502, 1990.

16. Park, W. H. et al. Acetylcholinesterase histochemistry of rectal suction biopsies in the diagnosis of Hirschsprung's disease. J Korean Med Sci, v. 7, p. 353-9, 1992.

17. Polley Jr, T. Z. et al. Suction rectal biopsy in the diagnosis of Hirschsprung's disease and chronic constipation. Pediatr Surg Int, v. I, p. 84-9, 1986.
18. Qualman, S. J.; Pysher, T.; Schauer, G. Hirschsprung disease: differential diagnosis and sequelae. Perspect Pediatr Pathol, v. 20, p. I | |-26, 1997.

19. Sieber,W. K. Hirschsprung's disease. In:WELCH, K.J. et al. Pediatric Surgery. 4 ed. Chicago:Year Book, 1986, p. 995-1020.

20. Swenson, O.; Fisher, J. H.; Macmahon, H. E. Rectal biopsy as an aid in the diagnosis of Hirschsprung's disease. N Engl J Med, v. 253, p. 632-5, 1955.

2I.Venugopai, S.; Mancer, K.; Shandling, B.The validity of rectal biopsy in relation to morphology and distribution of ganglion cells. J Ped Surg, v. 16, p. 433-7, 1981.

22.Wakely, P. E., Mcadams, A. J. Acetylcholinesterase histochemistry and the diagnosis of Hirschsprung's disease. A 3-1/2 year experience. Pediatric Pathology, v. 2, p. 35-46, 1984.

23. Yunis, E. J.; Dibbins, E.W.; Sherman, F. E. Rectal suction biopsy in the diagnosis of Hirschsprung disease in infants. Arch Pathol Lab Med, v. I00, p. 329-3, 1976.

\section{Mailing address}

Elizabeth S. Cugelmin Departmento de Patologia Hospital Infantil Pequeno Príncipe Rua Desembargador Motta, 1.070 CEP 80250-060 Curitiba-PR - Brazil Phone/Fax: +55 (41) 335-3939 e-mail: elizabeth@gugelmin.com 